\title{
Fare policies and a markup application based on airport cost
}

\author{
Reinaldo Moreira Del Fiaco ${ }^{1}$, Paulo Afonso Lopes da Silva ${ }^{2}$
}

${ }^{1}$ Military Institute of Engineering (IME/EB), cmtefiaco@gmail.com

${ }^{2}$ Military Institute of Engineering (IME/EB), pauloafonsolopes@uol.com.br

\section{Recebido:}

22 de março de 2018

Aceito para publicação:

30 de setembro de 2018

Publicado:

30 de abril de 2019

Editor de área:

Li Weigang

\section{Keywords: \\ Airport; \\ Regulation; \\ Fares; \\ Markup. \\ Palavras-chaves: \\ Aeroportos; \\ Regulamentação; \\ Tarifas; \\ Markup.}

DOI: 10.14295/transportes.v27i1.1640

\begin{abstract}
The experience gained by developed countries shows that airport administrators seeks to increase their profitability, and regulatory agencies aims to guarantee quality, investment and fair rates. States that are interested in having self-sustaining airports find in the regulations for the private initiative or mixed capital society the change they want. With the goal of developing an aeronautical fare pricing model based on airport cost, this paper presents an application of the Tornqvist index and the markup pricing method to find the market price opportunity. One of the specific goals is to compare the financial results based on ANAC Resolution No. 350/14 with the results obtained in the proposed model. For the forecast of demand with the new price of the fare, it was used the concept of elasticity. The scenario used was Campinas / Viracopos Airport, from January 2014 to March 2017. During the quarter in which there are no infrastructure construction costs, the price of the fare is $0.04 \%$ higher than the fare ceiling envisaged by ANAC. An independent method based on cost and market opportunity, but on which the financial statement should be audited, is shown to be promising in terms of increasing airport revenue. Establishing qualitative parameters may be the best option to ensure the quality of social welfare for passengers, and if these goals are not achieved, then fines can be applied to the airport administrator.
\end{abstract}

\section{RESUMO}

A experiência de países desenvolvidos mostra que os administradores aeroportuários procuram aumentar sua lucratividade, e as Agências Reguladoras objetivam garantir qualidade, investimento e tarifas justas. Os Estados, que se interessam em ter aeroportos autossustentáveis, encontram na regulamentação para a iniciativa privada ou sociedade de capital misto a mudança que desejam. Com o objetivo de desenvolver um modelo de precificação da tarifa aeronáutica baseada no custo do aeroporto, este artigo apresenta uma aplicação do índice de Tornqvist e do método de precificação Markup para encontrar a oportunidade de preço do mercado. Sendo um dos objetivos específicos de comparar os resultados financeiros com base na Resolução No. 350/14 da ANAC com os resultados obtidos no modelo proposto. Para a previsão de demanda com o novo preço da tarifa, utilizou-se o conceito de elasticidade. O cenário utilizado foi o do Aeroporto de Campinas/Viracopos, de janeiro de 2014 até março de 2017. Durante o trimestre em que não há custos com construção de infraestrutura, o preço da tarifa é $0,04 \%$ maior do que o teto tarifário previsto pela ANAC. Durante períodos com custo de construção, a média da tarifa foi 2,4 vezes maior em relação ao preço do Agente Regulador. Um método independente e baseado em custo e na oportunidade de mercado, mas no qual o demonstrativo financeiro deva ser seja fiscalizado, mostra-se ser promissor quanto ao aumento da receita do aeroporto. Estabelecer parâmetros qualitativos pode ser a melhor opção para exigir a qualidade do bem-estar social dos passageiros, e caso essas metas não sejam atingidas, então multas podem ser aplicadas a administradora aeroportuária. 


\section{INTRODUCTION}

Examples of international regulations show that it is possible to charge to the regulatory agency the responsibility for the readjustment of aeronautical fares and consequently the financial viability of the airport as a venture. Czerny (2006), Biggar (2012), Yang and Fu (2015) and Czerny and Zhang (2015) use optimization methods to determine the fare prices, and Fadloui (2012) uses multiple linear regression the same goal. In Brazil, each concession round from 2011 to 2017 received a different method to calculate the airport fare, all of which are not based on cost, using variables such as Euclidean distances of the competitor, the application of the Extended Consumer Price Index, factors of production and a quality index (ANAC, 2011, 2014, 2015).

Airport revenues are divided into non-operational and operational. It is considered as nonoperational revenues the financial investments, consulting and training, and operational revenues are divided into aeronautical and non-aeronautical. The aeronautical revenues include the fares related to the operations of embarkation, connection, landing, shipment, permanence, wharfage and storage, and of non-aeronautical tariffs are the rent of spaces for the promotion of advertising, commercial spaces, being able to collect participation in the profits, parking lots, counters check-in, and others (Brazil, 1973; Vojvodic, 2008; Tadeu, 2011; Young and Wells, 2014).

Revenue management must have well-defined and robust methods to maximize the airports and airlines profit. (Sousa, 2014). However, Rocha et al. (2016) consider that, in air transportation, the power of suppliers is strong and that of consumers is weak in relation to price choice, with consumers being only the price takers.

Serebrisky (2012) says that there is a question about what the best regulatory practice for pursuit of economic and financial balance is, especially in the period of conception of privatization or concession regulation, despite the recommendations made by ICAO (2013) and IATA (2017b). Also, according to Serebrisky (2012), the Latin American and Caribbean countries that privatized their airports in the early twentieth century faced the challenge of choosing the pricing model, and each country adopted a different method for calculate aeronautical fares.

When there is privatization, the tendency is to increase airport fares, for aiming the new administration's objectives, but these prices cannot be abusive for the market demand (Abeyratne, 2001). The concession of airports in the Latin American states, mainly at Brazil and Mexico, which are significant markets in world air transportation, allowed the perception of an administration focused on the measurement of performance, mainly operational and financial (Fernandes and Pacheco, 2016; TRB, 2010; Serebrisky, 2012), The privatization or concession process is usually accompanied by a new fare regulation policy (Czerny, 2006), and the operating costs, previously absorbed by the States, are now by operating revenues to compensate for the entry of the private agent into the airport administration (Serebrisky, 2012).

For Starkie and Yarrow (2013) each airline will react differently with the raise of aeronautical fares, depending on route performance, aircraft type, acceptance of passenger loss and revenue management. The proportion recognized by Starkie and Yarrow (2013) is: for each monetary unit of increase of the airport fares, there is an increase of one monetary unit in the airfare. Both authors cited the importance of the airport and the airline company to invest in price strategies. To establish the nomenclatures, it is considered as fare the price charged for airport services, airlines charges as the price of the airplane seat (airlines services), and airfare as the sum of the airport fare and airlines charges. 
Starkie and Yarrow (2013) consider that an airport can change the price of their own fare, according to their financial strategies and even when observing other airports fares. Fiuza and Pioner (2009) says the ideal model to determine airport fares are based on costs of the airport's inputs for each level of production, and from this one, should create an index of the operational cost, compatible with the financial risk to airport administration.

The aim of this paper is to develop an aeronautical fare pricing model based on airport costs by applying the Tornqvist index and the markup method. The Tornqvist index is found by the calculation of Total Factor Productivity (TFP), being a method to find the cost of one product according to the factory total cost and quantity produced (Dumagan and Ball, 2009). The specifics goals are not only to review the applicable pricing policies, reviewing the calculation methods found in the literature, and Brazilian regulations, but also to compare the prices of fares published by Brazilian Aviation Authority Agency (ANAC) with the fare calculated in the application of this paper.

\section{AIRPORT FARE POLICIES AND REGULATIONS}

Airport regulations have two types of fare segregation, single-till and dual-till. The first refers to the business model in which all aeronautical and non-aeronautical revenues are included. In the second, only aeronautical revenues are considered (Salgado and Fiuza, 2009; ICAO, 2013). For Czerny and Zhang (2015), the analysis of both tariff segregations should be focused on questions about the profits from each airport service.

There are two regulatory approaches for airports, cost-based pricing and non-cost-based pricing. The first one encourages investment in efficiency because it charges an aeronautical low-fare for airlines and passengers, as well as requiring the regulator to take specific care of each airport (Australian Government, 2011). For ANAC (2015), this approach refers to the cross subsidies between the origin of revenues and the adjustment rules for each case, aiming at the economic-financial balance. In the second approach, regulation is adjusted according to productivity, service quality and airport costs.

For Salgado and Fiuza (2009), the price-cap regulatory strategy is the system that should provide incentives to airport administrators, since if there is an optimization in the processes (cost reduction), the difference between revenue and costs would increase, that is, increase the profit. However, ACI-EU (2016) states that this regulatory strategy limits revenue opportunities with aviation tariffs.

Another regulatory strategy is cost-plus, also referred as a return rate regulation strategy (Dempsey, 2008, ICA0, 2013). The airport administrator sends the marginal costs to the regulatory agency, and a fare ceiling is defined (Salgado and Fiuza, 2009), whose objective is to limit a rate of return on investment to the airport (ICAO, 2013).

In the light-handed regulatory strategy, ICAO (2013) lists the requirements for its application: defining competitiveness laws, regulating benchmarking, and analyzing economic performance in financial and equity balances. However, this strategy must be "lighter" than traditional ones, not a deregulation, but the acceptance of an innovative approach that determines prices and new conditions (Arblaster, 2017).

In brief, the regulation will be single-till or dual-till, the approach cost-based pricing or noncost-based pricing, and the strategies price-cap, cost-plus or light-handed (Dempsey, 2008; Fuhr, 2008; Salgado and Fiuza, 2009; ANAC, 2015). 


\subsection{Pricing methods for aeronautical fares}

Table 1 presents the fare regulations, the approaches and the strategies found during the bibliographic review, as well as the summary of the methodology used by the various authors. It is noted that different methods are used for the same regulatory policy.

Table 1: Systematic review of regulations and pricing methods

\begin{tabular}{|c|c|c|c|c|}
\hline Fare Regulations & Approach & Regulatory Strategy & Summary & Reference \\
\hline \multirow[t]{8}{*}{ Single-till } & \multirow[t]{8}{*}{ Cost-Based pricing } & \multirow[t]{2}{*}{ Return Rate } & $\begin{array}{l}\text { Defines a financial index for the operating cost. Set- } \\
\text { ting a rate of return and using the yardstick compe- } \\
\text { tition method. }\end{array}$ & $\begin{array}{l}\text { Fiuza and Pioner } \\
\text { (2009); ICAO (2013) }\end{array}$ \\
\hline & & & $\begin{array}{l}\text { It finds the airport costs, corrected annually by a } \\
\text { consumer index. Find an equation that determines } \\
\text { the expected growth of passengers. And establishes } \\
\text { the fare, with the approval of the Government. }\end{array}$ & Littlechild (2012) \\
\hline & & \multirow[t]{2}{*}{ Price-cap } & $\begin{array}{l}\text { Maximum application of rate of return for a specific } \\
\text { period, adjustment in price according to a con- } \\
\text { sumer index, plus an incentive index (factor } \mathrm{x} \text { ). }\end{array}$ & $\begin{array}{l}\text { IATA (2017a); ICAO } \\
\text { (2013) }\end{array}$ \\
\hline & & & $\begin{array}{l}\text { It observes the change in demand and maximize } \\
\text { profit by adjusting the tariff and the level of service } \\
\text { quality, with the fare cap being pre-determined by } \\
\text { the regulator. }\end{array}$ & Yang and Fu (2015) \\
\hline & & Light-handed & $\begin{array}{l}\text { It observes the probability of the airport losing de- } \\
\text { mand and revenue if an increase of the airport fare } \\
\text { is realized. }\end{array}$ & Yang and Fu (2015) \\
\hline & & Undefined & $\begin{array}{l}\text { It applies the unpriced atomistic bottleneck (Nash) } \\
\text { equilibrium theory, by means of an analysis of sto- } \\
\text { chastic queue models, according to the cost of ter- } \\
\text { minal operation. }\end{array}$ & $\begin{array}{l}\text { Daniel and Harback } \\
\text { (2009) }\end{array}$ \\
\hline & & Undefined & $\begin{array}{l}\text { Application of Theory of Marginal Cost Pricing in ad- } \\
\text { dition to Airport profitability. }\end{array}$ & Abeyratne (2001) \\
\hline & & Price-cap & $\begin{array}{l}\text { Applies the price of the fare in relation to the cost } \\
\text { of the infrastructure, with the marginal revenue } \\
\text { equal to the marginal cost. }\end{array}$ & $\begin{array}{l}\text { Yang and Zhang } \\
\text { (2012); Czerny and } \\
\text { Zhang (2015) }\end{array}$ \\
\hline \multirow[t]{3}{*}{ Dual-till } & & \multirow[t]{2}{*}{ Price-cap } & $\begin{array}{l}\text { Applies the price of the fare in relation to the cost } \\
\text { of the infrastructure, with the marginal revenue } \\
\text { equal to the marginal cost. }\end{array}$ & \\
\hline & & & $\begin{array}{l}\text { Develops a Data Envelopment Analysis to find the } \\
\text { price of the fare, according to the best WLU index. }\end{array}$ & Curi et al. (2011) \\
\hline & & Light-handed & $\begin{array}{l}\text { It defines an equation that differentiates revenues } \\
\text { from airport costs by finding the airport fare accord- } \\
\text { ing to each service demand. }\end{array}$ & Fadlaoui (2012) \\
\hline
\end{tabular}

The minimum price of the aeronautical fare in single-till (ST) segregation, using the pricecap strategy, is in Equation 1, and the minimization process was applied to cover the Average Costs (Biggar, 2012). If the airport has a higher than expected actual demand, then you will get a positive Marginal Revenue.

$$
\tau^{S T}=\min \left\{\tau: \tau=\frac{\text { Average Costs }- \text { Marginal Revenue }}{\text { quantity } x \text { fare }}\right\}
$$

where $\quad \tau^{\mathrm{ST}}$ : $\quad$ single-till fare;

Czerny and Zhang (2015), when analyzing the Biggar (2012) method, concluded that if the airport has a lower demand than expected, it becomes necessary to determine a rate of return to find the cash balance.

Figure 1 shows a graph of passenger quantity (q) x single-till fare $\left(\tau^{\mathrm{ST}}\right)$. It is observed that profitability can be maintained with different fare prices. If the fare price is higher, the number of passengers is lower, and the financial result is compensated. If the price of the fare is lower, 
the number of passengers is greater, and the financial result is also compensated. This analysis was done by Czerny and Zhang (2015) using Equation 1.

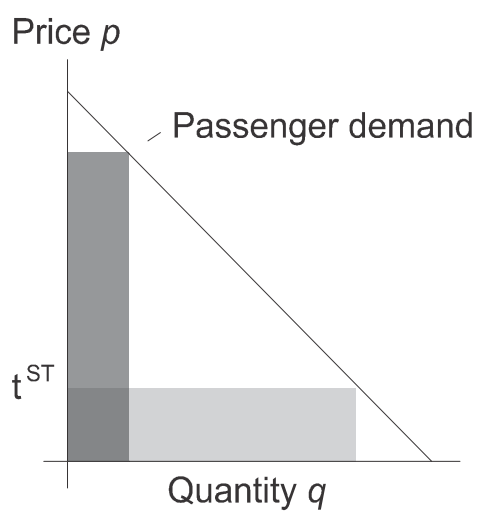

Figure 1. Rices and quantity per single-till price-cap with different fare prices. Available in: Czerny and Zhang (2015. p.9)

In the case of dual-till price-cap regulation $\left(\tau^{D T}\right)$ the price of the minimum tariff to be charged is represented by Equation 2 (Czerny and Zhang, 2015).

$$
\tau^{D T}=\min \left\{\tau: \tau=\frac{\text { Average Cost }}{\text { quantity } x \text { fare }}\right\}
$$

where $\quad \tau^{\mathrm{DT}}$ : dual-till;

Czerny (2006) has demonstrated that single-till regulation has advantages in maximizing profits compared to dual-till. The author assumes that airports and airlines can consider the demand for passengers by calculating airport fare, and non-aeronautical companies that serve passengers at the airport should consider their own prices for the calculation of demand elasticity. Czerny (2006) defines the objective function (3) to demonstrate the calculation of the fare in the regulation single-till price-cap $\left(\tau^{\mathrm{sp}}\right)$. The maximum fare price is given when the difference between cost and revenue is zero, and the average is based on costs per passenger and the profits from non-aeronautical revenues.

$$
\tau^{s p}=\max \left\{0, \frac{\operatorname{Cost}-p_{1} q_{1}\left(p_{0}, p_{1}\right)}{q_{1}\left(p_{0}, p_{1}\right)}\right\}
$$

$\begin{array}{lll}\text { where } & p_{0}: & \text { initial fare price; } \\ & p_{1}: & \text { final fare price; } \\ q_{0}: & \text { initial demand, and } \\ q_{1}: & \text { final demand. }\end{array}$

Fadlaoui (2012) carried out an empirical analysis between the price-cap and cost-plus regulatory strategies considering the price of the boarding fare $(t)$ (exogenous variable of the model). The study was applied at 11 German airports to identify the impact of the increase in the price of the embarkation fare on demand. This author used multiple regression (Equation 4) and the characteristics as type of airport ( $\left.\mathrm{X}_{1}\right)$ (hub, medium or regional), type of regulation $\left(\mathrm{X}_{2}\right)$, number of passengers $\left(\mathrm{X}_{3}\right)$, number of airlines $\left(\mathrm{X}_{4}\right)$, and number of aircraft movements $\left(\mathrm{X}_{5}\right)$, are considered as independent variables $\left(\mathrm{X}_{\mathrm{i}}\right)$, and being $\varepsilon_{1}$ a random variable for the error of the experiment.

$$
t=\beta_{0}+\beta_{1} X_{1}+\beta_{2} X_{2}+\beta_{3} X_{3}+\beta_{4} X_{4}+\beta_{5} X_{5}+\varepsilon_{1}
$$


The result found by Fadlaoui (2012) for the price-cap regulatory strategy is that if all nondummy independent variables are zero, the average price found at the airports hubs for the boarding fare would be $€ 2.121,32$. Already with the cost-plus strategy, the average result for the airports hubs would be $€ 1.702,56$. The conclusion of the author was that the price-cap strategy does not offer governmental incentives for the airport administrators, causing the airport fare to be higher.

Yang and Zhang (2012) show that the rate adjustment can be done both by measuring the quality of services and by the proven improvement in operational capacity, i.e., the rate can be increased if the airport is evaluated by the users or there is an increase in their operational capacity.

Yang and Fu (2015) consider that the viability of the airports is directly related to the financial result of the airlines, according to Equation 5.

$$
\pi_{n}=(\text { Profit }- \text { Variable Cost }- \text { Marginal Cost }) q_{1}
$$

where $\quad \pi_{1}: \quad$ airline financial result, and

$\mathrm{q}_{1}$ : the volume of airline traffic at an airport.

The solutions found by Yang and $\mathrm{Fu}$ (2015, p. 127) have maximized the financial profitability of airports ( $\pi$ ) using a light-handed proposal. In objective function (6), a fine is defined ( $p T$ ) if the airport does not achieve the desirable operational or financial capacity.

$$
\max \pi-p T=(u+h) x Q-\frac{S^{2}}{2}-K-p T
$$

where $\quad \mathrm{u}: \quad$ variable costs that interfere with the correction of the fare price;

$\mathrm{h}$ : revenue from commercial passenger services;

S: $\quad$ quality of services offered, and

K: $\quad$ fixed cost.

Yang and $\mathrm{Fu}$ (2015) conclude that performances and airport financial viability depend on many market factors, passengers and airlines aiming an excellent quality in airport services, but all of this increases the average cost pricing. For these authors, their investigation shows that light-handed regulation is promising for quality performance, and predicts demand based on welfare, but, for example, Australian public agencies and airlines do not agree in terms of higher fares that this type of regulation can generate. For these reasons, they suggest more studies based on price-cap, on cost-based and on optimization of the social welfare.

\subsection{Brazilian regulations on airport fares}

Although in Brazil the control by means of pricing is free and done by the airlines, the airport fares are controlled by the regulatory agent. According to the ANAC $(2015, \mathrm{p} .6)$ "the tariff setting did not follow a regulatory model, but made sporadically and according to the needs of INFRAERO or public policies." The Law 6.009/1973 (Brazil, 1973) allows annual adjustments for reaching the ceiling of airport fares.

The ANAC updated in 2011 the model of regulation of the airport tariffs of embarkation, landing and permanence, through Resolution $n{ }^{\circ} 180 / 11$. In the text of this resolution, ANAC says that the methodology for finding the tariff cap price was developed according to INFRAERO's operational data, since $95 \%$ of the total volume of passenger and cargo traffic in Brazil occurred in 66 airports administered by it in 2011 (ANAC, 2011; INFRAERO, 2012). Since then, the regulation has been based on the average airport costs of three previous years related 
to the collection period, which used the Extended National Consumer Price Index (IPCA) for the annual rate adjustment.

Article 3 of Resolution No. 180/11 states that airports may apply discounts without discrimination based on such items as quality of service, time, day and season. This article is in line with IATA's recommendation (2017b) that independent economic regulation should be nondiscriminatory and safeguard human rights without distinguishing several types of passengers. The same Resolution allowed fares to be increased up to $20 \%$ above the ceiling set by ANAC. If surpluses of collection prices are identified, then administrative measures would be taken to favor tariff modality (ANAC, 2011).

To increase airport revenue, the Law 12.648/12 (Brazil, 2012) reduced the percentage of Additional Airport Tariff (Adicional de Tarifa Aeroportuária - ATAERO) from 50\% to 35.9\%. Adding taxes, ATAERO and other fees, the gross remaining percentage for airports was about $32.55 \%$, and with this established in 2012, the percentage of revenue from tariff revenue under total gross revenue increased to $46.65 \%$.

In 2011, the airport concession program began, beginning with the São Gonçalo do Amarante airport (SBSG). The second round of concessions was held in 2012, in which private airports were granted to Brasília (SBBR), Guarulhos (SBGR) and Campinas (SBKP). With the Logistics Investment Program (PIL), the Galeão (SBGL) and Confins (SBCF) airports also began, the auction took place in 2012 and the contracts were signed in 2013. In 2015, a new step was announced for the PIL with the fourth round of concessions, with the concession of the airports of Fortaleza (SBFZ), Salvador (SBSV), Porto Alegre (SBPA) and Florianópolis (SBFL). However, the new Government elected in 2014 announced the Crescer Project in 2016 and these airports (SBFZ, SBSV, SBPA and SBFL) were auctioned only in 2017 (ANAC, 2017).

For the airports granted, the regulation was the one based on cost, according to ANAC Resolution 350/14, based on the concession model of SBSG. With the experience that ANAC and INFRAERO acquired in the first years of the concessioned airports, both have opted for a change of approach, now for the regulation not based on cost. Under Resolution No. 350/14, airport fares could be increased up to $100 \%$ of the amount of the fare celling set by ANAC (2014).

\subsubsection{Non-cost-based pricing methodology}

The non-cost regulation is applicable to the INFRAERO Network and concessioned airports (ANAC, 2015), since each concessioned airport can operate under the rules defined by contract with ANAC (ANAC, 2014). Decree $n^{\circ}$ 7.624/11 (Brazil, 2011), says in art. 7 that "in the operation of aerodromes granted, airport fares will be applied according to the fares regime established by ANAC". The calculation methodology of the fares changes according to the predetermined revisions in the contract with each concession, and, in general, and it is the result of the sum of equations 9 and 10, and the indicators of quality of services (IQS).

To compose the initial fare pricing, the Total Factor Productivity (TFP) is calculated using the Tornqvist index or the price of the fare previously found by INFRAERO's internal methodology (ANAC, 2015). After the composition of the price found through the TFP, the base for the adjustment of airport tariffs for the remaining years is the application of the broad national con sumer price index. Paragraph 2 of art. 7 of Decree 7.624/11 (Brazil, 2011) states that "tariff prices shall be adjusted annually by means of a consumer price index" (ANAC, 2015, p. 12).

Paragraph 1 of the same art. 7 states that fare gains should be used to provide operational efficiency and quality in the services provided by the concessionaire, and as a tool for evaluation 
and pricing, besides the qualitative indicators of efficiency indices (X Factor) and quality of services (IQS), the latter being performed through the Permanent Passenger Satisfaction Survey made by Civil Aviation Secretariat (Brazil, 2011).

After calculating the IPCA variation, the contracts of concession define the $\mathrm{X}$ Factor as shown in Equation 7. The adjustment of the price of the fare considers the investment in the increase of space at passenger terminal (TPAX) and the parking positions for aircraft (PA), both representing by percentage of operational gain (ANAC, 2013, p.2), and being a reduction of the price of the fare. For SBBR, SBGR and SBKP airports adjust fares with the reference base price of $2.06 \%$, and SBGL and SBCF use of $1.42 \%$.

$$
X \text { Factor }=1,0206 x[1-(T P A X+P A)]
$$

SBFL, SBFZ, SBPA and SBSV consider the X Factor the percentage of TFP, and use it as the reference the price previously practiced by INFRAERO.

In the same way, the $Q$ Factor is the result of the analysis of the following indicators of quality of services (IQS): direct services, and availability of equipment and facilities on the air side. IQS are composed of 29 performance indexes. According to Appendix D of the concession agreement, ANAC considers 15 IQS factors, each with a decrease factor. The readjustment of the Q factor may vary according to the agreement, with a minimum of $2 \%$ and a maximum of $7.5 \%$ in relationship of the price found after the sum of equations 9 and 10 (ANAC, 2011b).

\section{DEVELOPMENT OF THE EMPIRICAL MODEL}

The development of the model was divided into two parts: first, the description of the data, which presents the variables of macroeconomic and microeconomic panel, the movement of the airport and the operational history of flights; the second part, the development of the empirical model with the proposed delimitations. Fiuza and Pioner (2009) recommend that an ideal model for determining airport fares should be based on the costs of airport inputs, although Phang (2016) argues that cost-based regulation is fairer for the consumer that understand pricing and agrees to pay for that service.

\subsection{Description of the data}

For the development of the proposed model, macroeconomic, microeconomic, operational and tax rates are required.

Table 2 shows the definition of the input and output variables of the model.

Table 2: Model Input and Output Variables

\begin{tabular}{|c|c|c|}
\hline \multicolumn{2}{|c|}{ Acronyms } & \multirow{2}{*}{ Definitions } \\
\hline Input & Output & \\
\hline$T C_{i j}$ & $c t_{i j}$ & Total airport cost or total cost of the product ij* \\
\hline ATC $_{i j}$ & $a t c_{i j}$ & Average total cost* \\
\hline-- & $\operatorname{tpf}_{\mathrm{ij}}$ & Total Productivity of Factors \\
\hline PDPAX $_{i j}$ & $\operatorname{pdpax}_{i j}$ & Paid pax sum \\
\hline FRPAX $_{i j}$ & - & Free pax sum \\
\hline $\mathrm{QPAX}_{\mathrm{ij}}$ & $\operatorname{qpax}_{i j}$ qpax $_{\mathrm{ij}}$ & PDPAXij and FRPAXij sumq \\
\hline SEATS $_{\mathrm{ij}}$ & - & Number of seats offered by airlines \\
\hline SSEATS $_{\mathrm{ij}}$ & - & Quantity of seats sold and present at Microdata of Commercial Airfares (ANAC, 2017b) \\
\hline $\mathrm{EMBF}_{\mathrm{ij}}$ & $\mathrm{embf}_{\mathrm{ij}}$ & Embarkation fare* \\
\hline WARFij & - & Weighted average rate of the fare* \\
\hline WAAF $_{i j}$ & waaf $_{i j}$ & Weighted average of airfare* \\
\hline- & $\operatorname{Epaxpg}_{i j}$ & Seat elasticity with respect to WATRF $F_{i j}$ and SEATS $S_{i j}$ \\
\hline
\end{tabular}


The indexes i are considered for the type of aeronautical fares ( 1 is used for boarding and 2 for connection), and $\mathrm{j}$ for the destination, (1 for domestic and 2 for international).

The microeconomic variables can be found in the financial statements of airports, these variables being presented in Table 2. To find the Average Total Cost, we apply Equation 8, obtained from Vasigh et. al (2013).

$$
A T C_{i j}=\frac{T C_{i j}}{Y_{i j}}
$$

where Yij: $\quad$ quantity of product ij.

To calculate the Weighted Average Rate of the Fare (WARF), we used Equation 9, also from Vasigh et. al (2013):

$$
W_{A R F_{i j}}=\frac{\sum_{i=1 ; j=1 \text { or } 2}^{n}{\text { Airline } \text { Charges }_{i j}} \times \operatorname{SSEATS}_{i j}}{\operatorname{SSEATS_{ij}}}
$$

The operational variables can be found in the electronic portals of the airport administrator, in the Regulatory Agent and in the Ministry responsible for transportation (YOUNG and WELLS, 2014). For the model, the prices of PDPAX $\mathrm{ij}_{\mathrm{ij}}$ FRPAX $_{\mathrm{ij}}$ and $\mathrm{QPAX}_{\mathrm{ij}}$ are necessary, because they are the destination of domestic and international flights.

\subsection{Description of the empirical model}

To find the cost of each airport service is used the Tornqvist index. The use of this index is justified if the airport does not have the cost of its services (ANAC, 2015, p.14). The Equation 10 was obtained from Dumagan and Ball (2009), due to the amount of data available for the applications of this article.

$$
\frac{t f p_{i j t}}{t f p_{i j t-1}}=\prod_{i=1}^{n}\left(\frac{Y_{t}}{Y_{t-1}}\right)^{\frac{1}{2}\left[s_{i j t}+S_{i j t-1}\right]}
$$

where $\quad \mathrm{Yi}_{\mathrm{j} t \mathrm{t}}$ quantity of product $\mathrm{ij}$ at a given time $(\mathrm{t})$; and

$\mathrm{Si}_{\mathrm{j} t \mathrm{t}} \quad$ share of product revenue ij in total revenues in $\mathrm{t}$.

After finding the Tornqvist index for the product, the result is multiplied by the absolute price of the total cost of the airport, with the objective of determining the cost of the unit produced of the service, according to Equation 11.

$$
t c_{i j}=t f p_{i j} x|T C|
$$

With the $\mathrm{TC}_{\mathrm{ij}}$ prices found in the previous step, the result of the elasticity between the seat supply (ASS) and the WAAF is used to define the price per markup which is the percentage that the entrepreneur can generate of gross profit, and this method is mainly used by airlines (Vasigh et. al, 2013).

To find the prices of the aeronautical fares considered here, it is necessary to observe the offer of seats by all the airlines that operate in the determined airport, considering the destination, and applying in the pricing model of Starkie and Yarrow (2013). Equation 12 shows the calculation of the elasticity, and the result is classified as elastic when greater than 1, inelastic if less than 1 and unitary if equal to 1.

$$
\mathrm{E}_{\mathrm{p}}=\frac{\Delta \mathrm{SEAT}_{1 \mathrm{n}}}{\Delta_{\mathrm{WAAF}_{\mathrm{ij}}}} \times \frac{\text { WAAF }_{\mathrm{ij} 2}+\mathrm{WAAF}_{\mathrm{ij} 1}}{\mathrm{SEATS}_{1 \mathrm{n} 2}+\mathrm{SEATS}_{1 \mathrm{n} 1}}
$$

Vasigh et. al (2013) say that the model will correspond to prices more suitable for the market if the result is elastic or unitary. If the result is less than 1 it is pointed out that the supply has 
decreased, and that strategies to attract passenger demand, seat supply and cost reduction can be considered as an option by the airport administrator (Vega, 2012; Vashing et. al, 2013).

Equation 13 determines the price per markup (Vasigh et. al, 2013, p.337). If the elasticity result is negative, then the calculation should consider the markup formula as $\mathrm{ATC}_{\mathrm{ij}} \mathrm{x}\left(\mathrm{E}_{\mathrm{p}} / 1+\right.$ $\mathrm{E}_{\mathrm{p}}$.

$$
\text { Markup price }(\text { embfi })=A T C_{i j} x\left(1+\frac{E_{p}}{1+E_{p}}\right)
$$

\section{APPLICATION OF THE MODEL}

The chosen scenario was International Airport of Campinas / Viracopos (SBKP), which attracts a large volume of passenger traffic because it is the hub of Azul Airlines, and the Metropolitan Region of Campinas concentrates 20 municipalities representing $2.7 \%$ of the national GDP (Cappa and Souza Filho, 2017). It is also known that the highest revenue from the airport is derived from the movement of cargoes, as the region is a pole of industrial, agroindustry, aeronautical and educational attractiveness (Cappa and Souza Filho, 2017).

From 2014 to 2016, SBKP's largest revenue was from cargo business $(60,4 \%)$, followed by business with airlines (22.2\%), commercial revenues (10.6\%) and others. According to Cappa and Souza Filho (2017) the demand for 14 million passengers was expected for 2014, and in the planning of the concession for 2018, the amount of 22 million. Meanwhile, the handling (arrival / landing / connection) of passengers in 2014 was 9.84 million, with 5 million passengers paying the domestic embarkation fare from regular air transportation (Viracopos, 2015).

The application of the model consists in using the demand and the cost of domestic embarkation fare of regular air transportation to find the best price for the corresponding aeronautical fare, using the markup method. With the data obtained and demonstrated in the next subsection (4.1), the model could be done quarterly, from 2014 to the first quarter of 2017.

\subsection{Obtaining the data}

The economic, financial and operational prices were organized monthly. The Brazilian National Civil Aviation Agency (ANAC), the Central Bank of Brazil (BCB) and the World Bank have a data repository that directs the users of their networks to different databases, so it is necessary to differentiate this information. Table 3 shows the searched variables, the time series extension, the database name and the references.

Table 3: Structure and references of the data used

\begin{tabular}{|c|c|c|c|c|}
\hline Variables & Extension & Freq. & Data Base & References \\
\hline $\mathrm{TC}_{\mathrm{ij}}$ & jan./2014-mar./2017 & Quarterly & Corporate governance & Viracopos (2017) \\
\hline $\begin{array}{l}\text { PDPAX }_{i j} ; \\
\text { FRPAX }_{i j} ; \text { SEATS }_{i j} ;\end{array}$ & jan./2000-2017 & Month & $\begin{array}{l}\text { Statistical Database of Air } \\
\text { Transport }\end{array}$ & ANAC (2017b) \\
\hline SSEATS $_{\mathrm{ij}} ;$ WARF $_{\mathrm{ij}} ;$ & jan./2002-2017 & Month & $\begin{array}{l}\text { Microdata of Commercial } \\
\text { Airfares }\end{array}$ & ANAC (2017b) \\
\hline $\mathrm{EMBF}_{\mathrm{ij} ;}$ & jan./2010-dez./2011 & Month & Fares & ANAC (2017b) \\
\hline
\end{tabular}

Table 4 shows the operating prices. The sample released by the airlines of the WATRF corresponds to $45 \%$ of the total PDPPAX that flight to SBKP in 2014, 36\% of the total when compared to 2015 , and $28 \%$ corresponding to passengers paid in 2016 (ANAC, 2017b). 
Table 4: Demand, supply and tariff prices at Viracopos Airport

\begin{tabular}{lllllllll}
\hline Period & PDPAX $_{11}$ & FRPAX $_{11}$ & $\boldsymbol{Q P A X} \boldsymbol{X}_{11}$ & SEATS & WAAC* $^{*}$ & EMBF $_{11}{ }^{*}$ & WAAF $_{11}{ }^{*}$ & TC $_{11}{ }^{*}$ \\
\hline $2014.1^{1}$ & 1.172 .437 & 49.069 & 1.221 .506 & 1.609 .627 & 324,17 & 16,49 & 340,76 & -306.048 \\
$2014.2^{1}$ & 1.179 .020 & 47.509 & 1.226 .529 & 1.572 .685 & 323,43 & 16,49 & 340,02 & -304.206 \\
$2014.3^{1}$ & 1.221 .422 & 51.323 & 1.272 .745 & 1.518 .275 & 323,98 & 16,49 & 341,66 & -296.960 \\
$2014.4^{1}$ & 1.247 .247 & 51.610 & 1.298 .857 & 1.646 .262 & 360,15 & 17,68 & 377,83 & -665.273 \\
2015.1 & 1.204 .579 & 47.088 & 1.251 .667 & 1.645 .790 & 307,88 & 17,68 & 325,56 & -175.976 \\
2015.2 & 1.106 .233 & 45.109 & 1.151 .342 & 1.624 .014 & 337,06 & 17,68 & 354,74 & -194.365 \\
2015.3 & 1.173 .601 & 45.976 & 1.219 .577 & 1.482 .040 & 397,57 & 19,02 & 416,59 & -194.800 \\
$2015.4^{1}$ & 1.125 .890 & 49.623 & 1.175 .513 & 1.564 .928 & 415,56 & 19,02 & 434,58 & -265.578 \\
$2016.1^{1}$ & 1.067 .199 & 44.249 & 1.111 .448 & 1.528 .946 & 383,39 & 19,02 & 402,41 & -241.561 \\
2016.2 & 971.811 & 43.628 & 1.015 .439 & 1.468 .110 & 407,31 & 19,02 & 426,33 & -40.423 \\
$2016.3^{1}$ & 1.072 .785 & 46.507 & 1.119 .292 & 1.311 .289 & 414,62 & 20,36 & 434,98 & -241.424 \\
2016.4 & 1.083 .976 & 53.057 & 1.137 .033 & 1.394 .242 & 442,90 & 20,36 & 463,26 & -93.529 \\
2017.1 & 1.083 .724 & 47.779 & 1.131 .503 & 1.439 .904 & 381,23 & 27,67 & 408,91 & -128.348 \\
\hline
\end{tabular}

*Values in BRL (Brazilian Real) ${ }^{1}$ Period with high infrastructure investment (VIRACOPOS, 2017).

To obtain the tax prices, it was identified that from 2012 to December 2016, ATAERO was applied, corresponding to $35.9 \%$ of the total price of the boarding embarkation fare (Brazil, 1989). From 2017 onwards, ATAERO's collection was extinguished until the recovery of the economic-financial balance of the concession, according to the Law 13.319/2016 (Brazil, 2016). In Campinas-SP, the Tax on Services of Any Nature (ISSQN) corresponds to 5\% of the amount charged for airport services, according to Decree 25.508/05 (Campinas, 2005). DAC Ordinance No. 602 / GC-5 of September 2000 stipulated that airlines for collecting passenger fares could retain $3 \%$ of the amount of this charges, and the same ordinance also establishes that a percentage of $7.05 \%$ should be withheld from the fare, pursuant to Normative Instruction No. 1,234 / 12 of the Brazilian Federal Revenue (RFB, 2012).

\subsection{Results}

This section shows the results of the model, as described in the previous section. Table 5 shows the results of the Tornqvist index for each period and the $\mathrm{tc}_{\mathrm{ij}}$, according to Equations 10 and 11.

Table 5: Result of application of the Tornqvist index

\begin{tabular}{llllll}
\hline Period & tpf $_{11}$ & tc $_{11}{ }^{*}$ & Period & tpf $_{11}$ & tc $_{11}{ }^{*}$ \\
\hline 2013.4 & - & - & 2015.3 & 0,164181 & -31.982 .546 \\
2014.1 & 0,173761 & -53.179 .305 & 2015.4 & 0,158906 & -42.201 .807 \\
2014.2 & 0,180207 & -54.820 .041 & 2016.1 & 0,145267 & -35.090 .874 \\
2014.3 & 0,178204 & -52.919 .506 & 2016.2 & 0,094217 & -3.808 .536 \\
2014.4 & 0,177955 & -118.388 .518 & 2016.3 & 0,124462 & -30.048 .157 \\
2015.1 & 0,169242 & -29.782 .498 & 2016.4 & 0,152058 & -14.221 .861 \\
2015.2 & 0,146245 & -28.424 .972 & 2017.1 & 0,165661 & -21.262 .291 \\
\hline * Values in BRL (Brazilian Real) & & & &
\end{tabular}

The $\mathrm{tc}_{11}$ from the period of 2014.1 represents $17.4 \%$ of the $\mathrm{TC}_{11}$. The average of $\mathrm{tc}_{11}$ with domestic passengers is $15.6 \%$. The lowest tc 11 was in 2016.2, a period without no significant infrastructure investment (VIRACOPOS, 2017). Martín and Socorro (2009) says that a public airport must be budget-constrained to avoid higher charges and the bad use of public financial for infrastructure to subsidize a monopoly. For ACI-EU (2016), the private shareholders prefer 
an appropriate return on investment on a short-time. European Airport, in the period of 20052014, increased their capital costs, capacity and social-welfare, and the charges varied approximately $+130,5 \%$. When compared the price per passenger, the European Airports with higher investments presented lower cost in years than airports that do not made investments (ACI-EU, 2016).

The results of the elasticity, atc 11, embf $_{11}$, and waaf $f_{11}$ are shown in Table 6 . The result of the mean elasticity is greater and approximately equal to 1 . The higher elasticity was 1,240 in 2016.4, with embf 11 equals to $\mathrm{R} \$ 19,26,5,4 \%$ less than the ANAC's EMBF11 in a period without significant infrastructure investment.

In this model based on cost, there is a dispersion on embf 11 of $\mathrm{R} \$ 126,71$. Comparing the average of $\mathrm{EMBF}_{11}$ and embf 11 , respectively, we have the amounts of $\mathrm{R} \$ 18,99$ and $\mathrm{R} \$ 48,61$. So, the airport can then profit in average $\mathrm{R} \$ 29,50$ from the present application of the markup method, difference found according the analysis of cost, and the price opportunity. For a singletill regulation, the same opportunity was found by Czerny (2006), but this article has used the Tornqvist index to find the cost of domestic embarkation, instead of non-aeronautical revenue to reduce the aeronautical fare. The average embf 11 is 2,54 times more than ANAC's average ceiling, representing the market opportunity for airport embarkation fare.

Table 6: Markup price application result

\begin{tabular}{llllllllll}
\hline Period & Ep & atc $_{11}{ }^{*}$ & embf $_{11}{ }^{*}$ & waaf $_{11}{ }^{*}$ & Period & Ep & atc $_{11}{ }^{*}$ & embf $_{11}{ }^{*}$ & warf $_{11}{ }^{*}$ \\
\hline 2013.4 & - & - & - & - & 2015.3 & 0,981 & 26,22 & 39,78 & 437,35 \\
2014.1 & 0,834 & 43,54 & 63,57 & 387,74 & 2015.4 & 1,069 & 35,90 & 54,58 & 470,15 \\
2014.2 & 0,852 & 44,70 & 65,00 & 388,43 & 2016.1 & 1,084 & 31,57 & 48,51 & 431,90 \\
2014.3 & 0,832 & 41,58 & 60,63 & 384,61 & 2016.2 & 1,157 & 3,75 & 5,82 & 413,14 \\
2014.4 & 0,845 & 91,15 & 132,53 & 492,68 & 2016.3 & 1,236 & 26,85 & 41,71 & 456,33 \\
2015.1 & 0,831 & 23,79 & 34,69 & 342,57 & 2016.4 & 1,240 & 12,51 & 19,26 & 462,16 \\
2015.2 & 0,845 & 24,69 & 36,92 & 373,97 & 2017.1 & 1,173 & 18,79 & 28,94 & 410,17 \\
\hline
\end{tabular}

*Values in BRL (Brazilian Real)

The lowest embf11 is $\mathrm{R} \$ 5,82$ in 2016.2 , representing $69,3 \%$ less than the ANAC's celling. On the other hand, the highest price is $\mathrm{R} \$ 132,53$ in 2014.4, showing that with high investments the fares will be higher. According to the ICAO (2013), this is a characteristic for a rate of return based on cost regulation, type of regulation that may provide a strong incentive for over-investment to increase the profit. We can observe, in the Figure 1, that Czerny and Zhang (2015) said that in a single-till regulation, highest prices can represent low demand, and a breakeven point should be determinated.

\section{DISCUSSIONS}

If were followed the Czerny and Zhang (2015) model for a single-till regulation, the airport administrator would predict a passenger or other aeronautical revenue demand to be greater than the average cost, but the fixed cost should be greater than thebe cover with non-aeronautical revenue. This occur to minimize the risk of a divergent market reaction comparing to airport prediction of demand. The method used in this article, based on cost, Tornqvist index and markup is for a single-till regulation the services to generate the non-aeronautical services should be applied to the total cost, and then the productivity could be used for a benchmarking analysis. 
In this model, it was used the real demand to find the productivity index and the fare price. The prediction of demand is the fragile component for airport business plan. However, this method is recommended by ICAO (2013), that says that the full costs of the airports need to be determined, and the price of their services is also a fragile component. According to ANAC (2014a, 2015), responsible to establish the aeronautical fares, if in the end of the contract of concession, the airport shows a negative return of investment, the Government will recompose this investment until it reaches the price of zero.

As airlines have sophisticated methods to find their own prices, why airports cannot have their own methods by observing the non-discriminatory issues recommend by ICAO (2013) and IATA (2017b)? Despite the high price in periods of investment in infrastructure, it would be easier to find the break-even point by using the method proposed in this article, a suggestion for ANAC and other regulatory agencies for considering its applicability.

When airport charges are adjusted by a new policy, with higher prices than before, this fact can create a juridical dispute with airlines and only can be resolved if the country has an independent administrative council for economic defense and a strong antitrust law (Littlechild, 2012). For example, as made for German Airports, when applied the light-handed regulation and compared to Australian Regulation, Littlechild (2012) says that is necessary a framework agreement with an independent aviation regulatory agency monitoring investment, reducing litigation and defending the interests of passengers. Any increasing in airport charges could be interpreted as an action against public interest (Abeyratne, 2001), and on the other hand, the investment made to increase the social welfare can justify the higher prices?

The social welfare for passenger is a concern for Yang and Fu (2015), ICAO (2013) and ANAC (2014). Using a qualitative index to calculate the airport fares approach for a light-handed regulation, it is difficult the prediction of revenue and the budget for an optimal investment in quality of service. Establishing quantitative parameters may be the best option to ensure the quality of social welfare for passengers, and if these goals are not achieved, then fines can be applied to the airport administrator.

\section{CONCLUSIONS}

This paper presents an innovative method based on Tornqvist index and the markup/cost pricing to find the market price opportunity for aeronautical fare pricing. The method consists in pricing aeronautical fares after find the operating costs of each airport service using the Tornqvist index, applying the cost multiplied by the elasticity of the seat supply and the total weighted average of the airfare paid by the passengers.

The Tornqvist index has as an advantage the accounting facility for updating the share of the cost of a service under total cost. And the markup pricing model stands out, because it is a wellknown application for airlines that want to profit from market opportunities, being possible to obtain more predictable results when using the offer as a criterion of elasticity for the adjustment of aeronautics fares.

The scenario used was the Campinas Airport from 2014 to March 2017. Analyzing the results of the markup model prices and the financial statements, we conclude that in the periods when construction costs were higher, the price of the fare were will be higher. For having no major differences in the price of the fare for the passenger, the airport administration may distribute expenses and other actions in time construction for cost management.

By not using the non-aeronautical revenue to minimize the aeronautical revenue, it was 
showed the opportunity to gain with passenger's demand. When the markup average is an unity, it can be explained as the airlines has an optimal prices after using the embarkation fare and their own cost to find the price opportunity.

It is recommended to apply statistical methods to verify the impact of change airport fares on the passenger demand. It can also be verified the impact on demand when the price of the embarkation fare is applied with the $100 \%$ after the celling price, as stipulated by ANAC. Demand assessment studies for aeronautical and non-aeronautical fares can be made to verify the impact of prices on airport revenues.

\section{ACKNOWLEDGEMENTS}

The authors thank the Coordination for the Improvement of Higher Level Personnel - CAPES for the support provided to carry out this research.

\section{REFERENCES}

Abeyratne, R. (2001) ICAO: Some Recent Developments in Aviation and Environmental Protection Regulation. Environmental Policy and Law, 32 (1), p. 32-40.

ACI-EU (2016) Airport Council International - Europe. Leveraging Airport Investment To Drive The Eu's Aviation Strategy. Available at: <https://goo.gl/9u5iPK> (Access: 12/06/2016).

ANAC, Agência Nacional de Aviação Civil (2011) Resolução $n^{\circ}$ 180, de 25 de janeiro de 2011. Dispõe sobre o modelo de regulamentação das tarifas aeroportuárias de embarque, pouso e permanência e dos preços unificado e de permanência. Brasília, DF. (in Portuguese)

ANAC, Agência Nacional de Aviação Civil (2011a). Anexo 2 - Plano de Exploração Aeroportuária (PEA). Concessão para Construção Parcial, Manutenção e Exploração do Aeroporto Internacional de São Gonçalo do Amarante. Brasília, DF. (in Portuguese)

ANAC, Agência Nacional de Aviação Civil (2011b.). Anexo 13 - Metodologia de Cálculo do Fator X a Ser Aplicado no Primeiro Reajuste Tarifário. Concessão para Construção Parcial, Manutenção e Exploração do Aeroporto Internacional de São Gonçalo do Amarante. Brasília, DF. (in Portuguese)

ANAC, Agência Nacional de Aviação Civil (2013) Anexo 11 do Contrato de Concessão Fator X. Concessão para Ampliação, Manutenção e Exploração do Aeroporto Internacional Tancredo Neves/Confins. Brasília, DF. (in Portuguese)

ANAC, Agência Nacional de Aviação Civil (2014). Relatório de Atividades 2013. p. 107. Brasília, DF. (in Portuguese)

ANAC, Agência Nacional de Aviação Civil (2014a). Resolução n³50 de 19 dez. 2014. Brasília, DF. (in Portuguese)

ANAC, Agência Nacional de Aviação Civil (2015) Regulação Econômica de Aeroportos - Atuação da ANAC no âmbito da regulação econômica de tarifas aeroportuárias e preços específicos. Apresentação. ONLINE. Brasília, DF. (in Portuguese)

ANAC, Agência Nacional de Aviação Civil (2017) Concessões. ONLINE. (in Portuguese)

ANAC, Agência Nacional de Aviação Civil (2017a) Tarifas Aeroportuárias - Valor Teto das Tarifas de Embarque. Available in: <https://goo.gl/j6Ygv9> (acess 12/06/2016). (in Portuguese)

ANAC, Agência Nacional de Aviação Civil (2017b) Demanda e Oferta do Transporte Aéreo - Empresas Brasileiras. Available in: < https://goo.gl/wXi47z> (acess 12/06/2016). (in Portuguese)

Arblaster, M. (2017) Light-Handed Regulation of Airport Services: An alternative approach to direct regulation? Chapter 2 of The Economics of Airport Operations: Advances in Airline Economics, v. 6, 2017. p.15-47.

Australian Government. (2011) Economic Regulation of Airport Services. Productivity Commission Inquiry Report. Melbourne, n. 57. Available at: DOI: 10.1108/S2212-160920170000006002

BCB, Banco Central do Brasil (2017) Sistema Gerenciador de Séries Temporais - SGST. v. 2.1 Módulo público. ONLINE. (in Portuguese)

Biggar, D. (2012) Why Regulate Airports? A Re-examination of the Rationale for Airport Regulation. Jornal of Transport Economics and Policy, v. 46, part 3, p. 367-380. Available at: http://www.jstor.org/stable/24396317

Brazil. (1973) Lei $\mathrm{N}^{\circ}$ 6.009, de 26 de dezembro de 1973. Dispõe sobre a utilização e a exploração dos aeroportos, das facilidades a navegação aérea e dá outras providências. Diário Oficial [da] República Federativa do Brazil. Brasília, DF. DOFC de 28/12/1973, p. 13417. (in Portuguese)

Brazil. Constituição (1988). Constituição [da] República Federativa do Brasil. Senado Federal. Brasília, DF. (in Portuguese)

Brazil. (2011) Decreto $\mathrm{n}^{\circ}$ 7.624, de 22 de novembro de 2011. Dispõe sobre as condições de exploração pela iniciativa privada da infraestrutura aeroportuária, por meio de concessão. Diário Oficial [da] República Federativa do Brasil. Brasília, DF. (in Portuguese)

Brazil. (2011b) Medida Provisória $\mathrm{n}^{\circ}$ 551, de 22 de novembro de 2011. Altera Dispositivos das Leis no 7.920 , de 12 de dezembro de 1989, no 9.825, de 23 de agosto de 1999, no 8.399, de 7 de janeiro de 1992, no 6.009, de 26 de dezembro de 1973, no 5.862, de 12 de dezembro de 1972, no 12.462, de 5 de agosto de 2011; e dá outras providências. Diário Oficial [da] República Federativa do Brasil. Brasília, DF. (in Portuguese)

Brazil. (2012) Lei ${ }^{\circ}$ 12.648, de 17 de maio de 2012. Altera dispositivos das Lei $n^{\circ} 7.920$, de 12 de dezembro de 1989. Diário Oficial [da] República Federativa do Brasil. Brasília, DF. (in Portuguese) 
Brazil. (1989) Lei $n^{\circ}$ 12.648, de 17 de maio de 2012. Altera dispositivos das Lei $n^{\circ} 7.920$, de 12 de dezembro de 1989. Diário Oficial [da] República Federativa do Brasil. Brasília, DF. (in Portuguese)

Brazil. (2016) Edital n 1/2016 da Agência Nacional de Aviação Civil. Diário Oficial da República Federativa do Brasil, Poder Executivo, DF, 01 de dezembro de 2016, Capítulo 3, n. 230, p. 126-127. (in Portuguese)

Campinas - Município de Campinas, SP. Lei ${ }^{\circ} 12.392$, de 20 de outubro de 2005. Lei que regula o ISSQN. Campinas, SP. (in Portuguese)

Cappa, J. Souza Filho, J. V. (2017) Análise da Evolução do Imposto Sobre Serviços na Arrecadação Tributária no Município de Campinas - SP. Revista de Políticas Públicas, v. 21, n.1. Available at: DOI: 10.18764/2178-2865.v21n1p65-87 (in Portuguese)

Curi, C., Gitto, S., Mancuso, P. (2010). New evidence on the efficiency of Itatian airports: A bootstrapped DEA analysis. SocioEconomic Planning Sciences, 45, 84-93. Available at: DOI: 10.1016/j.seps.2010.11.002

Czerny, A.I. (2006) Price-cap Regulation of Airports: Single-till Versus Dual-till. Journal of Regulatory Economics, ed. 30, vol. 1, p. 85-97. Available at: DOI: $10.1007 / \mathrm{s} 11149-006-0010-9$

Czerny, A.I.; Zhang, A. (2015) Single-Till versus Dual-Till Regulation of Airports. Tinbergen Institute Discussion Paper. Tinbergen Institute, Amsterdam.

Daniel, J. I, Harback, K. T. (2009) Pricing the major hub airports. Journal of Urban Economics, v. 66, i. 1, p. 33-56.

Dempsey, P. S. (2008) Airport Finance. Air and Space Law, Graduation (Law Degrees and Certificate Programs), McGill University.

Dumagan, J.C., Ball, V.E. (2009) Decomposing growth in revenues and cost into price, quantity and total factor productivity contributions. Applied Economics, 41, p. 2943-2953. Available at DOI: 10.1080/00036840701367549

Fadlaoui, A. (2012) Impact of Price Regulation on Airport Charges - Airport charges and price regulation in Germany. Airlines Magazine. Online Journal on Air Transport for Aviation Business Students and Professionals.

Fernandes, E., Pacheco, R.R. (2016) The Casual Relationship Between GDP and Domestic Air Passenger Traffic in Brazil. Transportation Planning and Technology, 33 (7) p. 569-581. Available at: DOI: 10.1080/03081060.2010.512217

Fiuza, E.P.S.; Pioner, H.M. (2009) Regulamentação e Concorrência no Setor de Aeroportos. Série Estudos Regulatórios. Direção Nacional do Projeto BRA/01/801 ANAC-ICAO, Rio de Janeiro, RJ. (in Portuguese)

Fuhr, J. The Institutional Arrangements Between Airlines, Airports, and Handling Companies: A Transaction Cost Assessment. The Technical University of Berlin for obtaining the academic degree (The faculty of Economics and Management). Berlin, 2008.

Gujarati, D. N.; Porter, D. C. (2012) Basic Econometrics. 5 ed. McGraw-Hill.

IATA (2017b) International Air Transport Association. Economic Regulation of Airports and Air Navigation Services Providers. Airport and ATC Charges Positions. ONLINE.

ICAO (2013) International Civil Aviation Organization. International. Airport Economics Manual. Doc 9562. Third Edition. Montreal.

INFRAERO (2012). Empresa Brazileira de Infraestrutura Aeroportuária. Relatório Anual 2011. Brasília, DF. (in Portuguese)

Littlechild, S. C. (2012). German Airport Regulation: framework agreements, civil law and the EU Directive. Jounal of Air Transport Management, v. 21, p. 63-75. DOI: 10.1016/j.jairtraman.2011.12.018

Martín, J.C., Socorro, M.P. (2009) A new era for airport regulators through capacity investments. Transportation Research Part A, v.43, p.618-625. Available at DOI: 10.1016/j.tra.2009.04.001

Phang, S.-Y. (2016) A General Framework for Price Regulation of Airports. Journal of Air Transport Management, v.51, p.39-45. Available at DOI: 10.1016/j.jairtraman.2015.11.001

Tadeu, H. F. B. (2011) Logística Aeroportuária - Análises setoriais e o modelo de cidades-aeroportos. Campinas: Cengage Learning, 296 p. (in Portuguese)

Vasigh, B.; Fleming, K.; Tacker, T. (2013) Introduction to Air Transport Economics: From Theory to Applications. ed. 2. Ashgate Publishing.

Vega, D. J. G. (2012) A Methodology to Forecast Air Transportation Demand with Alternative Econometric Models. Thesis presented to the Instituto Tecnológico de Aeronáutica, in partial fulfillment of the requirements for the Degree of Master in Science. São José dos Campos, SP.

Viracopos - Aeroportos Brasil (2015). Estatística e Publicações. Resumo da Movimentação Aeroportuária de 2014. Institucional. ONLINE. (in Portuguese)

Viracopos - Aeroportos Brasil (2017) Governança Corporativa. Demonstrações Financeiras. Institucional. ONLINE. (in Portuguese)

Vojvodic, K. (2008) Airport Concession. ed. 1. EKON. MISAO PRAKSA DBK GOD XVII, p. 95-104.

Vose, D. (2008) Risk Analysis: A quantitative guide. $3^{\circ}$ Ed. John Wiley and Sons, p. 752.

RFB, RECEITA FEDERAL BRAZILEIRA (2012) Instrução Normativa RFB n 1.540, de 05 de janeiro de 2015. Diário Oficial [da] República Federativa do Brasil. Brasília, DF. (in Portuguese)

Salgado, L. H., Fiuza, E. (2009) Marcos Regulatórios no Brazil - É tempo de Rever Regras? IPEA - Instituto de Pesquisa Econômica Aplicada. Secretaria de Assuntos Estratégicos da BRAZIL. Rio de Janeiro. (in Portuguese)

Senado Federal (2016a) Projeto de Lei do Senado $N^{\circ} 258$. Brasília, DF. (in Portuguese)

Serebrisky, T. (2012). Airport Economics in Latin America and the Caribbean: Benchmarking, Regulation and Pricing. Directions in Development: Insfraestructure. The World Bank, Washington, D.C. Available at DOI: 10.1596/978-0-8213-8977-5 
Sousa, E. (2014) Retorno Operacional Sobre o Ativo (ROA): Análise do desempenho das companhias listadas no Segmento Novo Mercado da BMandFBOVESPA. Anais do $5^{\circ}$ Congresso UFSC de Controladoria e Finanças and Iniciação Científica em Contabilidade. Florianópolis. (in Portuguese)

Starkie, D.; Yarrow, G. (2013) Why Airports Can Face Price-Elastic Demands: margins, lumpiness and leveraged passenger losses. International Transport Forum.

TRB (2010) Transportation Research Board. Developing an Airport Performance-Measurement System. Airport Cooperative Research Program - ACRP Report 19. Washington, DC. Available at DOI: 10.17226/14428

Yang, H.; Fu, X. (2015) A Comparison of Price-Cap and Light-handed Airport Regulation with Demand Uncertainty. Transportation Research Part B. Available at DOI: 10.1016/j.trb.2015.02.002

Yang, H.; Zhang A. (2011) Price-cap Regulation of Congested Airports. Journal of Regulatory Economics, v. 39, pp. $293-312$.

Young, S.; Wells, A. (2014) Aeroportos - Planejamento e Gestão. $6^{\circ}$ Ed. Porto Alegre: Bookman, 539 p. (in Portuguese) 